\title{
Evaluation of Sugar-Cane Bagasse as Bioadsorbent in the Textile Wastewater Treatment Contaminated with Carcinogenic Congo Red Dye
}

\author{
Aline Sartório Raymundo ${ }^{1}$, Romina Zanarotto ${ }^{1}$, Marciela Belisário ${ }^{1}$, Madson de Godoi \\ Pereira $^{2}$, Joselito Nardy Ribeiro ${ }^{1}$ and Araceli Verónica Flores Nardy Ribeiro ${ }^{3 *}$ \\ ${ }^{I}$ Núcleo de Biotecnologia; Departamento de Ciências Fisiológicas; Universidade Federal do Espírito Santo; Av. \\ Marechal Campos s/n; 29040-091; Vitória - ES - Brasil. ${ }^{2}$ Departamento de Ciências Exatas e da Terra; \\ Universidade do Estado da Bahia; Rua Silveira Martins, 2555; 41195-001; Salvador - BA - Brasil. ${ }^{3}$ Coordenadoria \\ de Licenciatura em Química; Centro Federal de Educação Tecnológica do Espírito Santo; Av. Vitória, 1729; \\ 29040-780; Vitória - ES - Brasil
}

\begin{abstract}
A methodology involving sugar cane bagasse bioadsorbent was developed in order to remove the carcinogenic congo red dye from aqueous medium. The results showed high efficiency with retention of $64 \pm 6 \%$ in synthetic congo red solution and $94 \pm 5 \%$ in effluent enriched with congo red, at $10.0 \mathrm{~g}$ of the bioadsorbent. The adsorption system provided a maximum adsorption capacity of $4.43 \mathrm{mg} / \mathrm{g}$. Tests showed independence adsorption properties, when compared with the column flow rates. The treatment units could be operated with flexibility. From the results, it was possible to conclude that sugar cane bagasse could be an adequate bioadsorbent.
\end{abstract}

Key words: Sugar cane bagasse, congo red, bioadsorption

\section{INTRODUCTION}

Impacts on hydric resources are more intense each day regarding contamination caused by the products and sub - products from the most varied productive processes. The domestic, agriculture and industrial wastes significantly contribute to the pollution process (Koening et al., 2003; Pedrozo and Rocha, 2007), but the textile, chemical and paper industries, and oil refineries generate huge volume of wastes (Guaratini et al., 2000; Thompson et al., 2001; Wake, 2005).

The effluents generated by the textile industries have high pollutant potential due to dyes consumption in the tinting stage and the consumption of additives (fixers, anti-foaming and anti-fungi) during the pre-tinting and storage stages. Textile dyes are organic compounds which provide colors to the cellulose fibers. They may be classified in accordance to their chemical structure (anthraquinone, azo, etc.) or by the methods used to fix them on textile fibers (reactive, direct, azoic, acid, disperse, etc) (Guaratini et al., 2000).

One of the main difficulties in treating the textile effluents is the strong color due to the non-fixing of excessive dye added to fibers during tinting operations (Kunz et al., 2002). If the colored effluent is discharged in a body of water, without

*Author for correspondence: araceli@ cefetes.br 
the correct treatment, it affects the water aesthetics and clearness. It diminishes the solubility of gases, exhibits accumulative effects on the organisms and causes adverse effects on human beings (Guaratini et al., 2000). It might alter the biosynthesis process due to the reduction of sunlight penetration (Amaral et al., 2004). Besides, there is a concern about the interaction of these effluents in the water treatment stations, since it may provoke diverse problems of economical and public health order, given that some kinds of textile dyes can lead to allergies (Seidenari et al., 2006), dermatitis (Hatch and Maibach, 1995) and tumors (Golka et al., 2004). Congo red, for example, is a type of textile dye that has carcinogenic properties (Chatterjee et al., 2007).

Owing to the adverse environmental effects, some processes to remove the dyes from the textile wastewater have been evaluated including the use of bioadsorbents. Active carbon is the most used adsorbent (Namasivayam and Kavitha, 2002; Lin et al., 2008; Ong et al., 2008); however, due to its high cost and considering the huge quantities of wastewater to be treated, efforts have been made to use the bioadsorbents of considerable lower cost, such as cellulose (Annadurai et al., 2002), chitosan (Chatterjee et al., 2007), sawdust (Garg et al., 2003), sugar cane (Khattri and Singh, 1999; Pandey et al., 2000), Brazilian pine-fruit shell (Lima et al., 2008) and others agricultural residues (Chandran et al., 2002). The adsorption process has demonstrated to be relevant when compared to other techniques for water reuse, since it has very low initial cost, easy operation, flexibility and simplicity. For this process to be efficient, in addition to its low cost, it is necessary to choose an adsorbent with high adsorptive capacity, high selectivity, stability and availability (Crini, 2006).

The bioadsorbent made using sugar cane bagasse is basically built by macromolecules with humic and fulvic substances, lignin, cellulose, hemicelluloses and proteins that have adsorptive sites such as carbonyl, carboxylic, amine and hydroxyl groups, able to adsorb the dyes by the ion exchange phenomena or by complexation (Dávila-Jiménez, 2005). Besides the characteristics described, the bioadsorbent are found in high quantities at a low cost. In Brazil, and at the Espírito Santo State, an average of $30,760,165$ and 86,823 tones of sugar cane were produced in 2008, respectively (UNICA, 2009), which represented the production of a huge amount of cane bagasse. It is important to highlight that the use of agricultural wastes for the treatment of aqueous effluents, primarily as alternative adsorbent materials, may be an advantage, since they remove inert pollutants from the wastewaters and may contribute to minimize the environmental impacts caused by inadequate disposal of these wastes.

This study aimed to assess the capacity of sugar cane bagasse to remove the carcinogenic congo red textile dye (Fig. 1) by using the adsorption process. The following parameters were evaluated: $\mathrm{pH}$, residence time for bagasse (adsorbent) and dye (adsorbate), particle size of the adsorbent, mass quantity of the adsorbent material, dye concentration and percolation flux. Later, the optimized methodology was employed on the treatment of a real sample collected from a textile industry wastewater from Espírito Santo, which contained more than one kind of dye.

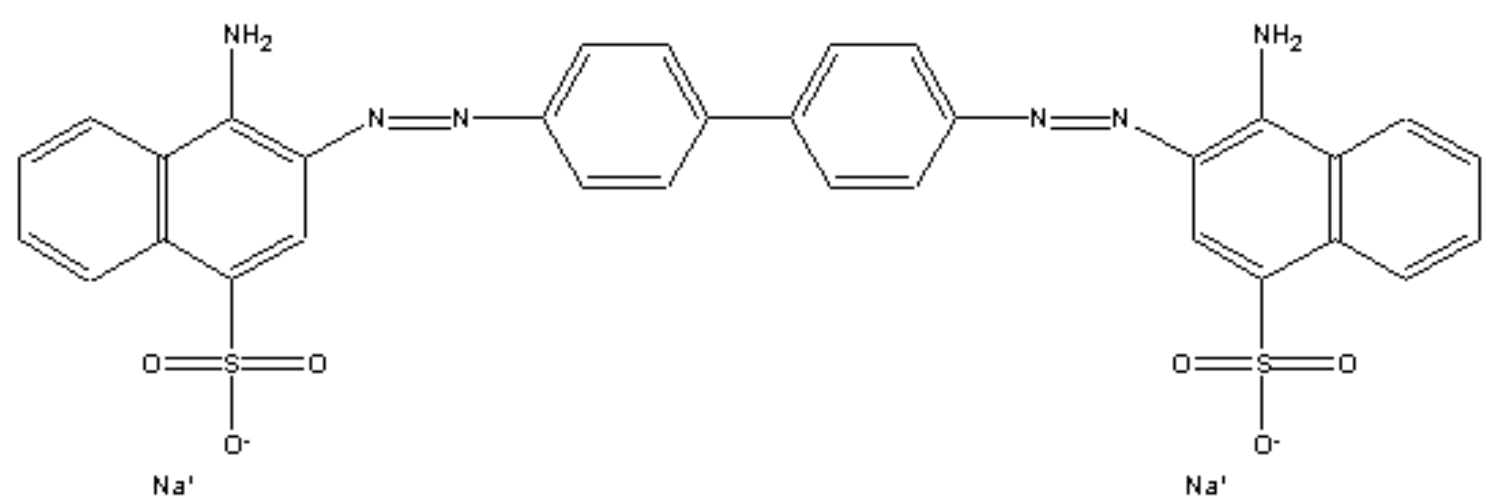

Figure 1 - Congo red dye structure. 


\section{MATERIALS AND METHODS}

\section{Materials}

The following equipments were used during the accomplishment of this work: analytic scale, potentiometer, UV/Vis spectrophotometer, agitation plate, mesh sieves $1.19,2.38$ and 4.76 $\mathrm{mm}$, industrial blender, glass percolation column $4 \times 30 \mathrm{~cm}$, as well as other glassware usually used in a chemistry laboratory.

\section{Reactants}

The reactants of analytical degree and deionized water $\left(18.2 \mathrm{M} \Omega \mathrm{cm}^{-1}\right)$ were used to prepare all the solutions. The following reactants were used: congo red dye (Vetec, Brazil), chlorhydric acid (Vetec, Brazil) and sodium hydroxide (Dinâmica, Brazil). The sugar cane bagasse was provided by DISA Ethanol industry, Conceição da Barra (Espirito Santo state, Brazil) and the sample of textile wastewater was obtained from the Blink Jeans Industry, Vila Velha (Espirito Santo state, Brazil).

\section{Procedures}

Analytical blank solutions were adopted in all the experimental stages and the analyses were carried out in triplicates. The following values of $\lambda_{\max }$ were used in all the absorbance measures: 560 , 560, 500, 500, and $490 \mathrm{~nm}$, for $\mathrm{pH} \mathrm{4,} \mathrm{6,} 8$ and 10, respectively. A $\lambda_{\max }$ of $530 \mathrm{~nm}$ was adopted in the experiments related to percolation of industrial wastewater enriched with congo red.

\section{Adsorptive material preparation}

The sugar cane bagasse was dried at room temperature and it was further triturated in an industrial blender. Then, the adsorbent material was divided in three different particle sizes $\varnothing \leq$ $1.19 \mathrm{~mm}$ (size 1$) ; 1.19<\varnothing \leq 2.38 \mathrm{~mm}$ (size 2); $2.38<\varnothing \leq 4.76 \mathrm{~mm}$ (size 3). After that, the material obtained was packed in hermetically sealed containers and then labelled.

Optimization of variables: $\mathrm{pH}$, residence time and particle size

The solutions of congo red dye were prepared with a concentration of $10 \mu \mathrm{M}$ at $\mathrm{pH} 4,6,8$ and $10.3 \mathrm{~g}$ of sugar cane bagasse, of the different sizes described above, were transferred to the beakers, then added $100 \mathrm{ml}$ of each of the dye solutions, for each different $\mathrm{pH}$ value. The mixtures were magnetically agitated and the residence time was assessed. The following times were evaluated: 5, 20, 35 and $60 \mathrm{~min}$. After that, the mixtures were filtered and the supernatant was analysed in an $\mathrm{UV} / \mathrm{V}$ is spectrophotometer.

\section{Optimization of the adsorbent mass and building of the Langmuir isotherm}

Different adsorbent masses (4.0, 6.0, 8.0, 10, 12 and $14 \mathrm{~g}$ ), of particle size 3 , were transferred to yhe beakers. Later, $100 \mathrm{ml}$ of the $100 \mu \mathrm{M}$ dye solution ( $\mathrm{pH} 10)$ were added to each beaker, followed by $5 \mathrm{~min}$. of magnetic agitation. Then, the mixtures were filtered and the supernatants were analysed in an UV/Vis spectrophotometer. Earlier data was used to build the Langmuir isotherm. The best working conditions for the batch system were $10 \mathrm{~g}$ of adsorbent with size 3 , dyeing solution at $\mathrm{pH} 10$ and concentration of 100 $\mu \mathrm{M}$, residence time of $5 \mathrm{~min}$. The working temperature was $25^{\circ} \mathrm{C}$. In order to determine the remaining concentrations of congo red in the supernatants obtained after each point of the isotherm, a calibration curve was built using standard solutions of dye $(2$ to $10 \mu \mathrm{M})$. The supernatants were diluted, when necessary.

\section{Optimization of the percolation flux}

Ten grams of sugar cane bagasse were added to the percolation columns $(4 \times 30 \mathrm{~cm}$; particle size $3)$. One hundred milliliters of a congo red solution $(100 \mu \mathrm{M}$ and $\mathrm{pH} 10)$ were percolated through each column. The following flux rates were evaluated: $2.0 ; 7.0 ; 9.0 ; 11.0 ; 47.0$ and $52.0 \mathrm{ml} / \mathrm{min}$. The supernatants were collected and analysed with a spectrophotometer within the visible region.

\section{Treatment of industrial effluent enriched with congo red}

A sample of textile effluent was enriched with a certain quantity of congo red dye in order to obtain a final dye concentration of $100 \mu \mathrm{M}$. The effluent was maintained at its natural condition $(\mathrm{pH} \mathrm{5)}$. Aliquots of $50 \mathrm{ml}$ of enriched wastewater were percolated through the columns containing $5 \mathrm{~g}$ of sugar cane bagasse (particle size 3 ) with a flux rate of $2 \mathrm{ml} / \mathrm{min}$. Then, eluates were analysed by molecular absorption spectrophotometry in the UV/Vis. For determining the dye content retained in the adsorbent material, $\lambda_{\max }(530 \mathrm{~nm})$ and its maximum absorbance were determined. These data were compared to data obtained for the eluate 
from the wastewater enriched with congo red after going through the column

\section{RESULTS AND DISCUSSION}

Optimization of variables: $\mathrm{pH}$, residence time and particle size

Since several solutions of congo red dye were prepared $(\mathrm{pH} \mathrm{4,6,8}$ and 10), spectral scannings were carried out to obtain different $\lambda_{\max }$ values. It was observed that the solutions color changed from solid blue $(\mathrm{pH} \mathrm{4})$ to solid red $(\mathrm{pH} 6,8$ and $10)$ by changing the medium acidity and, consequently, the wavelength of the maximum absorbance was modified too. Figure 2 shows the data obtained for $\mathrm{pH}$ influence, residence time and particles size on the congo red adsorption by sugar cane bagasse. The highest percentages of adsorption occurred at $\mathrm{pH} 10$, being approximately 65,75 and $82 \%$ for the particles size 1 to 3 , respectively. Thus there was a higher efficiency on the dye removal when carried out with the bagasse at $\mathrm{pH}$ 10. This result was in accordance to literature. Namasivayam and Sumithra (2005) observed that the methylene blue dye showed higher adsorptions at a basic $\mathrm{pH}$, due to the negative charge present at the adsorber surface Iron (III) / Chromium (III) hydroxide. The particles size of cane bagasse has a strong effect on the adsorptive processes when the diameter reduction of particles achieves the $\mu \mathrm{m}$ scale.
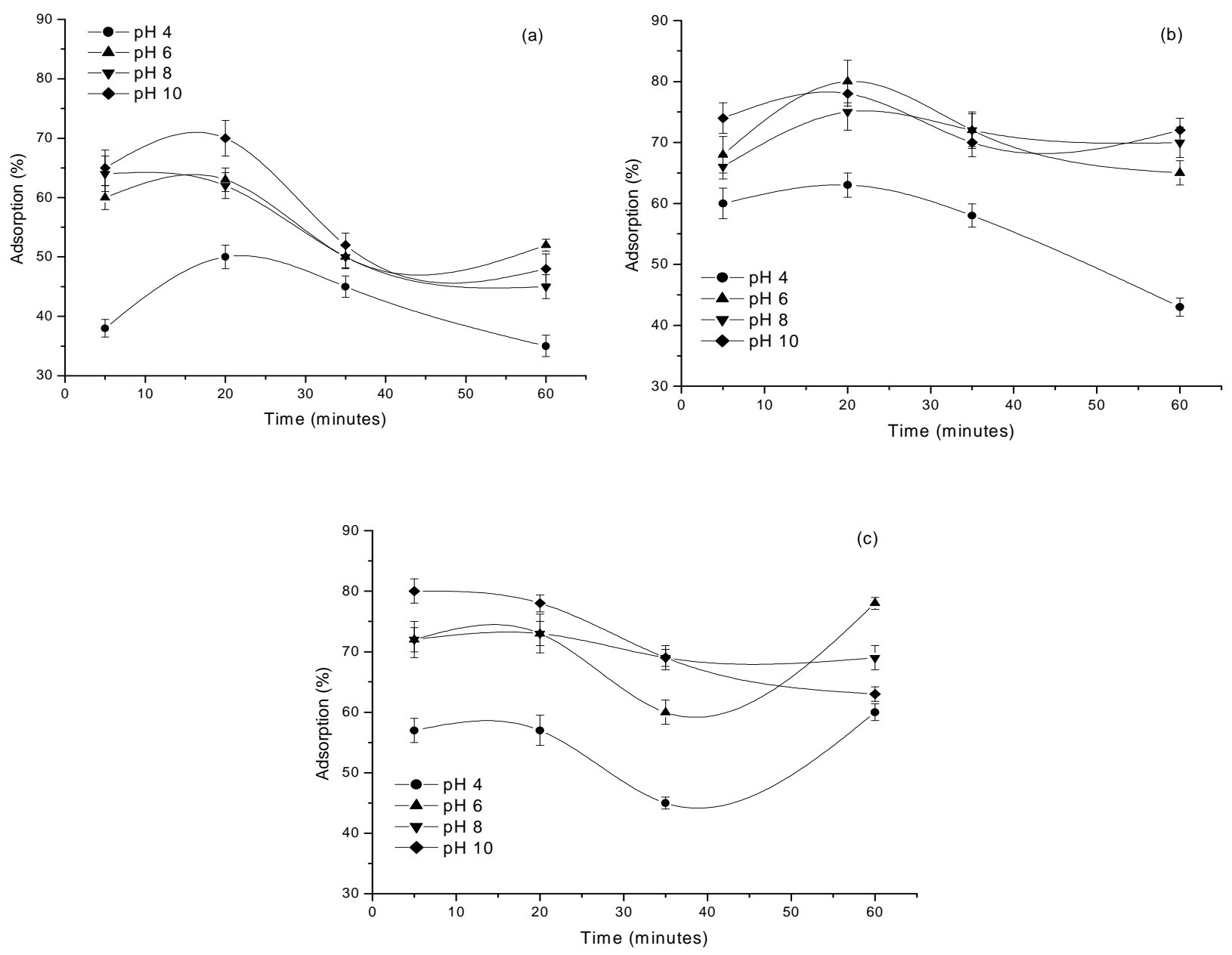

Figure 2 - Percentage of congo red adsorption as a function of the residence time for the following particles size: (a) $1(\varnothing \leq 1.19 \mathrm{~mm})$; (b) $2(1.19<\varnothing \leq 2.38 \mathrm{~mm})$ and (c) $3(2.38<\varnothing \leq 4.76 \mathrm{~mm})$. 
In these situations, increasing the contact area compensates possible reductions on pores quantity. On the other hand, for not so small diameters, as in the case of this study, diminishing the pores quantity exceeds the discrete increasing of the surface area. This explanation has been supported by others authors. Kimura et al (1999) observed that the adsorption of reactive dyes (Blue 2 , Black 5 and Orange 16) comprised as a function of the porosity decreasing on adsorbent particles (reticulated chitosan). Figure 2 also showed that higher dye amounts were observed after $5 \mathrm{~min}$ agitation, for particles size 1 to 3 . For a period of $20 \mathrm{~min}$, the approximate values of adsorption obtained were $c a:$ : 70,75 and $80 \%$, respectively. Therefore, a certain similarity could be perceived for the values obtained at 5 and $20 \mathrm{~min}$, which demonstrated favourable kinetics for the adsorption of congo red molecules. Desorption of congo red from the bagasse is likely to occur at 20 and $60 \mathrm{~min}$, due to the system's constant stirring and weak interactions between the dye and bioadsorbent (Namasivayam and Arasi, 1997; Rajeshwari et al., 2001).

\section{Optimization of the adsorbent mass}

Figure 3 shows the results obtained by varying the adsorbent mass. It was observed that with masses of 4.0 to $8.0 \mathrm{~g}$, adsorption percentages near $80 \%$ were obtained. For 10.0 to $14.0 \mathrm{~g}$, the adsorption percentage increased to approximately $88 \%$, showed that a mass of $10.0 \mathrm{~g}$ was enough to remove a good amount of the congo red dye. The mass quantity of adsorbent material to be used is of great importance, not only to have an efficient removal of the dye, but also to project the area required to stock the adsorbent material resulting from the treatment.

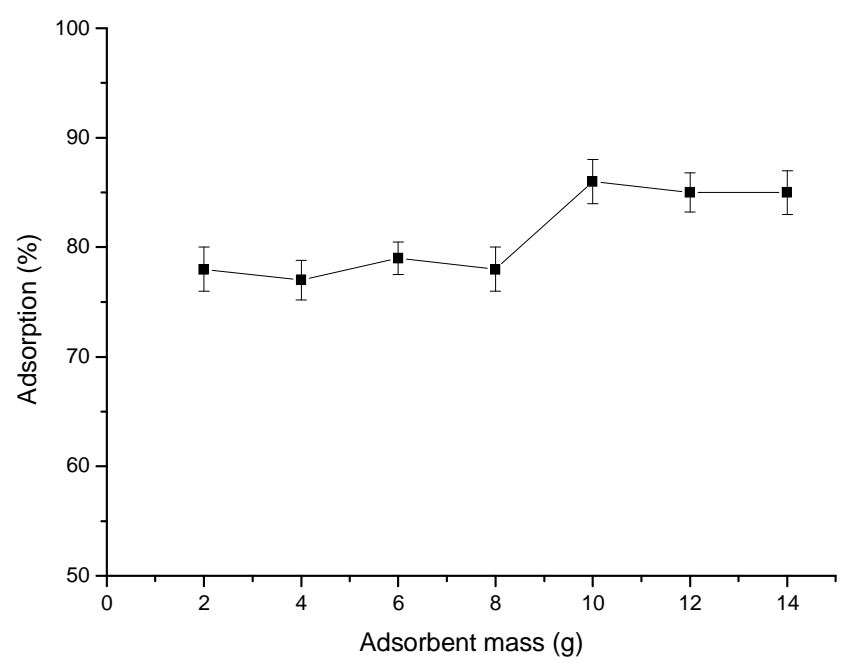

Figure 3 - Congo red adsorption percentage as a function of the adsorbent mass.

From these data, an adsorption isotherm was built, following the Langmuir model (Fig. 4). Following literature recommendations (Pereira and Arruda, 2003), the isotherm was linearized and the maximum adsorptive capacity of cane bagasse for the congo red dye was established at $4.43 \mathrm{mg} / \mathrm{g}$, which was a satisfactory value when compared to other congo red adsorbents such as red mud (4.05 $\mathrm{mg} / \mathrm{g}$ ) (Namasivayam and Kavitha, 2002) and activated carbon $(6.7 \mathrm{mg} / \mathrm{g}$ ) (Namasivayam and
Arasi, 1997). It must be highlighted that the maximum adsorptive capacity described was calculated from the batch experiments, which could not be totally extrapolated to dynamic systems, as those based on percolation columns. Therefore, in spite of the relevance of adsorption isotherms, they only offered theoretical forecasts about the adsorptive phenomena, while the experiments in columns provided the real potentialities of a certain adsorbent. 

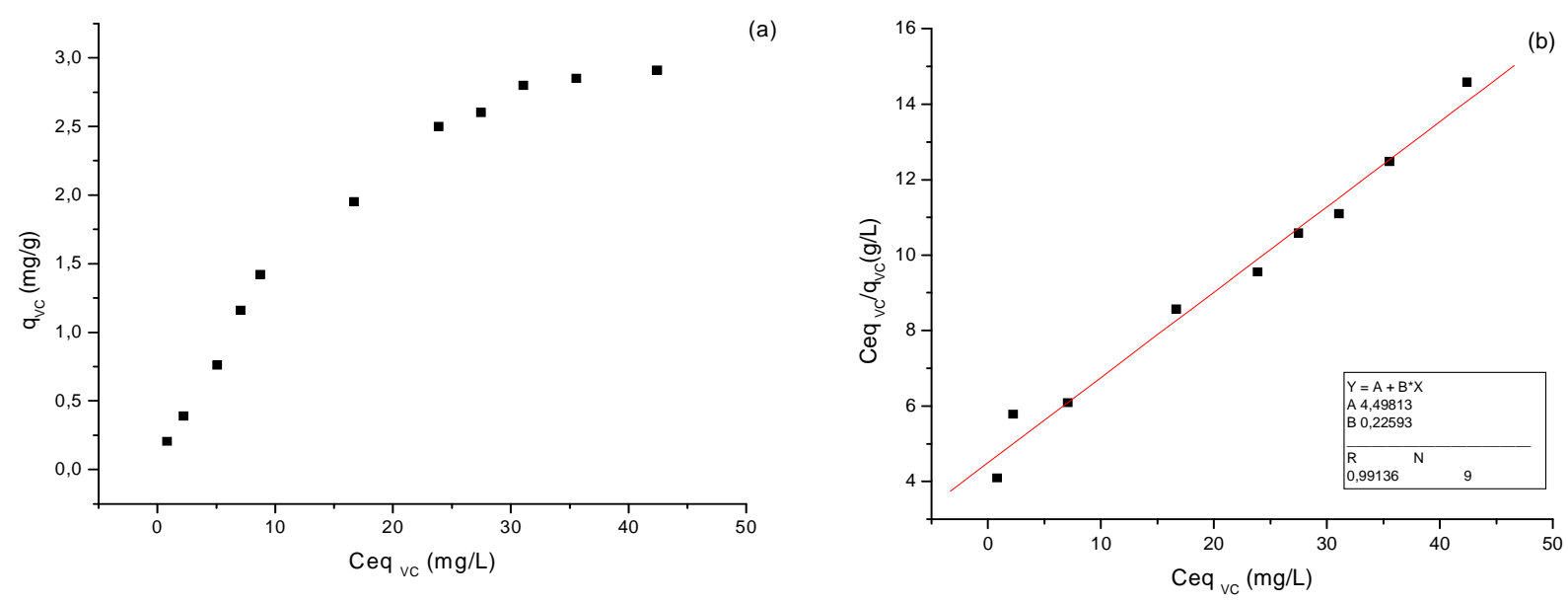

Figure 4 - Adsorption isotherm for congo red. (a) Langmuir isotherm; (b) Lagmuir isotherm linearization.

\section{Percolation flux optimization}

The results obtained for the percolation time are shown in Figure 5. It could be observed that the adsorption value was similar for all the flux rates studied, in other words, about $64 \pm 6 \%(64 \pm 6 \mu \mathrm{M}$ of congo red). This result yet demonstrated a reasonable efficiency for the dye removal. This percentage could be explained by the lack of homogeneity of solids, including cane bagasse (Khattri and Singh, 1999). This decrease in the dye adsorption (of $c a$. 80 to $60 \%$ ) could be ascribed to the rough granulometry of bagasse particles that provided a scarce contact (dye - particles) in fix bed systems, as was the case of percolation columns (Lazlo, 1996). The independence of adsorptive percentage as a function of percolation fluxes could be convenient for textile industries because this could help the industries to treat their wastewater at higher or lower speeds, depending on the volume of the wastewater produced. For the percolation purposes, the use of cane bagasse, with particle diameters smaller that the ones used here, might not be interesting, since small diameters would result on constant clogging of the columns, which, at last would turn the columns use unfeasible for the treatment systems. Additionally, obtaining particles with reduced diameter would cause a higher difficulty for the assembly and operation of adsorption columns.

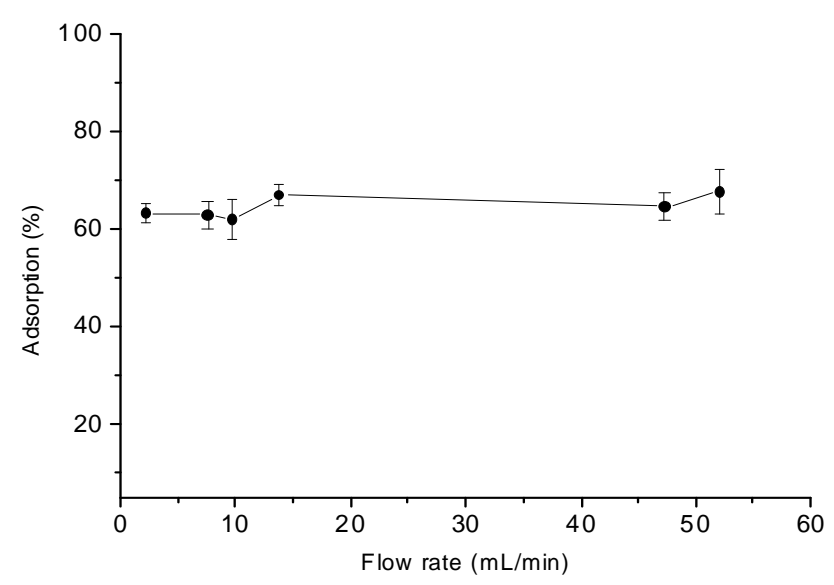

Figure 5 - Congo red adsorption percentage as a function of the percolation flux. 


\section{Treatment of industrial effluent enriched with congo red dye}

Textile industries release effluents with different $\mathrm{pH}$ values (from 4 to 10). Thus, it was decided to check the influence of $\mathrm{pH}$ on the adsorptive process of congo red by cane bagasse. It was observed that the best working $\mathrm{pH}$ was 10 . However since the industrial effluent has $\mathrm{pH} 5$, this $\mathrm{pH}$ was used. The effluent's natural $\mathrm{pH}$ was chosen to turn the treatment feasible for the business and for working with the lowest percolation flux $(2.0 \mathrm{~mL} / \mathrm{min})$. The results showed that the removal of congo red was of $94 \pm 5 \%$ while the removal of other dyes, probable Indigo Blue, was of $84 \pm 4 \%$. This was calculated comparing the dyes absorbance before and after taking the effluent through the percolation column. Therefore, it could be concluded that the adsorbent studied was an efficient remover of the congo red dye, as well as of other dyes, which could be used for the textile effluents treatment at industrial scale. Since the effluents from textile areas usually have more than one kind of dye in their composition, this process its feasibility to the treatment.

Even though the bioadsorption is an efficient method for removing the pollutants, an issue remains: what to do with the contaminated bagasse? Some authors have suggested that incineration or pollutant recovery would be efficient methods for solving this problem. (Volesky, 1990; Pino et al., 2006).

\section{ACKNOWLEDGMENTS}

The authors thank to Fundação de Apoio à Educação, Pesquisa e ao Desenvolvimento Tecnológico e Científico from the Centro Federal de Educação Tecnológica do Espírito Santo FUNCEFETES, for providing scholarships to A.S.R. and R.Z. and also thank to Fundação de Apoio a Ciência e Tecnologia do Espírito Santo FAPES, for the financial support. The authors furthermore thank to Disa and to Blink Jeans textile industry for providing the adsorption material (sugar cane bagasse) and the textile effluent, respectively.

\section{RESUMO}

Neste trabalho foi desenvolvida uma metodologia de remoção do corante carcinogênico congo red de sistemas aquosos. Os resultados mostraram uma elevada eficiência de remoção sendo de $64 \pm 6 \%$ para soluções sintéticas de vermelho congo, e $94 \pm$ $5 \%$ para efluente industrial enriquecido com vermelho congo utilizando $10 \mathrm{~g}$ de bioadsorvente. A capacidade máxima adsotiva encontrada foi de $4,43 \mathrm{mg} / \mathrm{g}$. Os testes de percolação revelaram independência das porcentagens adsortivas em relação às vazões das colunas. Estes resultados indicam viabilidade de uso do bagaço de cana-deaçucar no tratamento de efluentes contendo o congo red.

\section{REFERENCES}

Amaral, P.F.F., Fernandes, D.L.A., Tavares, A.P.M., Xavier, A.B.M.R., Cammarota, M.C., Coutinho, J.A.P., Coelho, M.A.S. (2004), Decolorization of Dyes from textile wastewater by Trametes versicolor. Environ. Technol., 25, 1313-1320

Annadurai, G., Shin Juang, R., Jong Lee, D. (2002), Use of cellulose-based wastes for adsorption of dyes from aqueous solutions. J. Hazard. Mater., 92, 263274

Chandran, C.B., Singh, D., Nigam, P. (2002), Remediation of textile effluent using agricultural residues. Appl.Biochem. Biotech., 102, 207-212

Chatterjee, S., Chatterjee, S., Chatterjee, B.P., Guha, A.K. (2007), Adsorptive removal of congo red, a carcinogenic textile dye by chitosan hydrobeads: Binding mechanism, equilibrium and kinetics. Colloid Surface A., 299, 146-152

Crini, G. (2006), Non-conventional low-cost adsorbents for dye removal: A review. Bioresource Technol., 97, 1061-1085

Dávila-Jiménez, M.M., Elizalde-González, M.P., Peláez-Cid, A.A. (2005), Adsorption interaction between natural adsorbents and textile dyes in aqueous solution. Colloid Surface A., 254, 107-114

Garg, V.K., Gupta, R., Yadav, A.B., Kumar, R. (2003), Dye removal from aqueous solution by adsorption on treated sawdust. Bioresource Technol., 89, 121-124

Golka, K., Kopps, S., Myslak, Z.W. (2004), Carcinogenicity of azo colorants: influence of solubility and bioavailability. Toxicol. Lett., 151, 203210

Guaratini, C.C.T., Zanoni, M.V.B. (2000), Textile dyes. Quím. Nova, 23, 71-78 
Hatch, K.L., Maibach, H.I. (1995), Textile dye dermatitis. J Am. Acad. Dermatol., 32, 631-639

Khattri, S.D., Singh, M.K. (1999), Colour removal from dye wastewater using sugar cane dust as an adsorbent. Adsorpt. Sci. Technol., 17, 269-282

Kimura, I.Y., Gonçalves, A.C.J., Stolberg, J., Laranjeira, M.C.M., Fávere, V.T. (1999), Efeito do pH e do tempo de contato na adsorção de corantes reativos por microesferas de quitosana. Pol. Cienc. Tecnol., 3, 51-57

Koening, M.L., Leça, E.E., Neumann-Leitão, S., Macedo, S.J. (2003). Impacto of the construction of the Port of Suape on phytoplankton in the Ipojuca River Estuary (Pernambuco-Brazil). Braz. Arch. Biol. Technol., 46, 73-81

Kunz, A., Zamora, P.P., Moraes, S.G., Durán, N. (2002). New tendencies on textile effluent treatment. Quim. Nova, 25, 78-82

Laszlo, J. A. (1996), Preparing an ion exchange resin from sugarcane bagasse to remove reactive dye from wastewater. Text. Chem. Color., 28, 13-17

Lima, E.C., Royer, B., Vaghetti, J.C.P., Simon, N.M., Cunha, B.M., Pavan, F.A., Benvenutti, E.V., Cataluna-Veses, R., Airoldi, C. (2008), Application of Brazilian pine-fruit shell as a biosorbent to removal of reactive red 194 textile dye from aqueous solution Kinetics and equilibrium study. J. Hazard. Mater., 155, 536-550

Lin, J.X., Zan, S.L., Fang, M.H., Qian, X.Q. (2008), Study on the adsorption of dyes using diatomite and activated carbon. Rare Metal Mat. Eng., 37, 682-685

Namasivayam, C., Arasi, J.S.E. (1997), Removal of congo red from wastewater by adsorption onto waste red mud. Chemosphere, 34, 401-417

Namasivayam, C., Kavitha, D. (2002), Removal of congo red from water by adsorption onto activated carbon prepared from coir pith, an agricultural solid waste. Dyes Pigments, 54, 47-58

Namasivayam, C., Sumithra, S. (2005), Removal of direct red 12B and methylene blue from water by adsorption onto $\mathrm{Fe}$ (III)/Cr (III) hydroxide, an industrial solid waste. J. Environ. Manag., 74, 207215
Ong, A.S., Toorisaka, E., Hirata, M., Hano, T. (2008), Combination of adsorption and biodegradation processes for textile effluent treatment using a granular activated carbon-biofilm configured packed column system. J. Environ. Sci. China, 20, 952-956

Pandey, A., Soccol, C.R., Nigam, P., Soccol, V.T. (2000), Biotechnological potential of agro-industrial residues. I: sugarcane bagasse. Bioresource Technol., 74, 69-80

Pedrozo, C.S., Rocha, O. (2007), Environmental quality evaluation of lakes in the Rio Grande do Sul coastal plain. Braz. Arch. Biol. Technol., 50, 673-685

Pereira, M.G., Arruda, M.A.Z. (2003), Vermicompost as a natural adsorbent material: characterization and potentialities for cadmium adsorption. J. Brazil. Chem. Soc., 14, 39-47

Pino, G.H., Mesquita, L.M.S., Toren, M.L., Pinto, G.A.S. (2006), Biosorption os cadmium by green coconut shell powder. Miner. Eng. 19, 380-387

Rajeshwari, S., Namasivayam, C., Kadirvelu K. (2001), Orange pell as an adsorbent in the removal of acid violet 17 (acid dye) from aqueous solutions.

Seidenari, S., Manzini, B.M., Danese, P.D. (2006), Contact sensitization to textile dyes: description of 100 subjects. Contact Dermatitis, 24, 253-258

Thompson, G., Swain, J., Kay, M., Forster, C.F. (2001), The treatment of pulp and paper mill effluent: a review. Bioresourse Technol., 77, 275-286

UNICA-União da Indústria de Cana-de-Açúcar e MAPA-Ministério da Agricultura, Pecuária e Abastecimento.

http://www.unica.com.br/downloads/estatisticas/prod ucaoacucar.xls. Access in march, 2009.

Volesky, B. (1990), Biosorption of heavy metals. CRC Press, Boca Raton, pp.315-316

Wake, H. (2005), Oil refineries: a review of their ecological impacts on the aquatic environment. Estuar. Coast. Shelf. S., 62, 131-140
Received: October 03, 2008 ; Revised: February 18, 2009; Accepted: February 04, 2010. 